\title{
PEMENUHAN HAK DAN KEWAJIBAN WARGA NEGARA INDONESIA
}

\author{
Nama : Ayu Wardani \\ NIM : 10200120204 \\ Kelas : Hukum Tata Negara E \\ Dosen : Kusnadi Umar, M.H
}

\begin{abstract}
ABSTRAK
Hak Azasi Manusia, Hak dan Kewajiban Warga Negara,Hukum Positif. PendahuluanHak dan Kewajiban Warga Negara dalam batas-batastertentu telah difahami orang,akan tetapi karena setiap orangmelakukan akitivitas yang beraneka ragam dalam kehidupan kenegaraan, maka apa yang menjadi hak dan kewajibannya seringkali terlupakan. Dalam kehidupan kenegaraan kadangkala hak warga negara berhadapan dengan kewajibannya.Bahkan tidak jarang kewajiban warga negara lebih banyakdituntut sementara hak-hak warga negara kurang mendapatkanperhatian.Hak dan kewajiban warga negara dalam kehidupankenegaraan maupun hak dan kewajiban seseorang dalam kehidupan pribadinya, secara historis tidak pernah dirumuskansecara sempurna, karena organisasi negara tidak bersifat statis.
\end{abstract}

Artinya organisasi negara itu mengalami perkembangan sejalandengan perkembangan manusia. Kedua konsep hak dan kewajiban warga negara/manusia berjalan seiring. Hak dan kewajiban asasi marupakan konsekwensi logis dari pada hakdan kewajiban kenegaraan juga manusia tidak dapat mengembangkan hak asasinya tanpa hidup dalam organisasinegara.Hak dan kewajiban warga negara dan hak asasi manusia dewasa ini menjadi amat penting untuk dikaji lebih mendalam mengingat negara kita sedang menumbuhkan kehidupandemokrasi. Betapa tidak, disatu pihak implementasi hak dankewajiban menjadi salah satu indikator keberhasilan tumbuhnya kehidupan demokrasi. Dilain pihak hanya dalam suatu negara yang menjalankan sistem pemerintahan demokrasi, hak asasi mnusia maupun hak dan kewajiban warganegara dapat terjamin. Hak asasi manusia marupun hak dan kewajiban warganegara sebagai salah satu elemen penting dari demokrasi disamping supremasi hukum, telah diatur dalam UUD 1945.Pengaturantersebutbersifat pokokpokok saja sehingga memerlukan penjabaran baik melalui ketetapan MPR maupunperaturan perundang-undangan sebagai produk bersama DPRdan Presiden.Pengaturan hak asasi manusia maupun hak dan kewajibanwarga negara secara lebih operasional ke dalam pelbagaiperaturan perundang-undangan amat bermanfaat.

Pengaturandemikian ituakan menjadi acuan bagi penyelenggara negaraagar terhindar dari tindakan sewenang-wenang tatkala mengoptimalisasikan tugas kenegaraan. Sedangkan bagimasyarakat/warga negara hal itu merupakan 
pegangan/pedoman dalam mengaktualisasikan hak-haknyadengan penuh rasa tanggung jawab. Akan tetapi bagaimana substansi HAM maupun hak dan kewajiban warga negara Indonesia dalam perundang-undangan/ hukum positif menarikuntuk menjadi bahan kajian. Dengan kejelasan substansitersebut dapat memotivasi warga untuk memahaminya lebih mendalam serta memberdayakan hak dan kewajibannya dalam konteks pelaksanaan otonomi dan semangat demokratisasi didaerah.

\section{A. PENDAHULUAN}

Dalam konteks negara hukum, konstitusi merupakan suatu bentukkodifikasi dari kesepakatan tertinggi antar manusia yang berkehendak bersama(social contract)untuk terikat dalam suatu negara. Kontitusi tidak hanya menjadipedoman dalam sistem penyelenggaran negara tetapi juga mengatur wewenangdan kewajiban pemerintah serta memberikan jaminan perlindungan hak dasar bagiwarga negara Indonesia maupun asing(constitusional rights)sekaligus menjadisumber hukum tertinggi dalamsistem hukum yang berlaku.(Judhariksawan,2017).Undang Undang Dasar sebagaiconstitusional rightmenyatakan bahwalndonesia adalah negara hukum yang salah satu elemen dasarnya adalahpemenuhan, pengakuan dan penjaminan akan hak-hak dasar warga negara yangsering disebut dengan hak warga negara(citizen right).

Dari berbagai literaturhukum tata negara maupun ilmu politik kajian tentang ruang lingkup pahamkonstitusi (konstitusionalisme) terdiri dari: anatomi kekuasaan (kekuasaan politik)tunduk pada hukum,jaminan dan perlindungan hak-hak asasi manusia, peradilan yang bebas dan mandiri, dan pertanggungjawaban kepada rakyat (akuntabilitaspublik) sebagai sendi utama dari asas kedaulatan rakyat. (Dahlan Thaib,2017)Sri Soemantri menyatakan bahwa UUD sebagai Konstitusi tertulismerupakan sebuah dokumen formal yang berisi: Hasil perjuangan politik bangsadi waktu yang lampau, Tingkat-tingkat tertinggi perkembangan ketatanegaraanbangsa, Pandangan tokoh-tokoh bangsa yang hendak mewujudkan, baik untukwaktu sekarang maupun untuk masa yang akan datang, dan Suatu keinginan,dengan nama perkembangan kehidupan ketatanegaraan bangsa hendak dipimpin.

Fenomena tersebut menjadikan konstitusi sebagai hukum yang tertinggi(supremacyof law) yang harus ditaati oleh rakyat maupun oleh alatalatkelengkapan negara baik eksekutif, legislatif maupun badan pemerintah lainnya.(NHT Siahaan, Subiharta, 2007)Ditegaskan pada dalam norma hukum Pasal 2 Undang-Undang Nomor 12Tahun 2011 tentang Pembentukan Peraturan PerundangUndangan yangmenyebutkan bahwa UUD 1945 merupakan hukum dasar dalam PeraturanPerundang-undangan.

Dimanajenis dan hierarki Peraturan Perundang-undanganterdiri atas: UndangUndang Dasar Negara Republik Indonesia Tahun 1945,Ketetapan Majelis 
Permusyawaratan Rakyat,Undang-Undang/PeraturanPemerintah Pengganti UndangUndang, Peraturan Pemerintah, PeraturanPresiden, Peraturan Daerah Provinsi dan Peraturan Daerah Kabupaten/Kota.Dalam UUD 1945 yang terdapat pada Bab X A Pasal 27 , Pasal 28memuat berbagai hak asasimanusia, yang dimulai dari Pasal $28 \mathrm{~A}$ sampai denganPasal 28J.

Hak-hak tersebut tidak dapat dipisahkan dari diri manusia (in alienablerights). Hak asasi manusia yang selanjutnya disebut HAM setiap warga negaralndonesia maupun warga negara asing diakui dan dilindungi selama berada diwilayah hukum negara Republik Indonesia dimana telah dijamin secarakonstitusional dalam wadah UndangUndang Dasar 1945 (Rn Syamsiah: 16).Selain dijaminnya hak asasi manusia secara universal dalam UUD 1945 terdapatpula hak-hak yang hanya berlaku bagi warga negara yang bersifat khusus dalamartian hanya bagi warga negara Indonesia misalnya hak atas pekerjaan (Pasal 27 ayat (2), hak atas pendidikan (Pasal 28C), hak dipilih dan memilih, hak ikut sertadalam pemerintahan dan lain-lain (Rn Syamsiah,2016).

\section{B. METODE PENELITIAN}

a) Ingin tahu tentang kewajiban warganegara

b) Ingin mngetahui apa itu warga negara

c) Ingin mengenal tentang warganegara

d) Apa fungsi dari kewarganegaraan

\section{PEMBAHASAN}

Kewarganegaraan merupakan keanggotaan seseorang dalam kontrol satuan politik tertentu yang dengannya membawa hak untuk berpartisipasi dalam kegiatan politik. Seseorang dengan keanggotaan yang demikian disebut warga negara. Seorang warga negara berhak memiliki paspor dari negara yang dianggotainya.maka apa yang menjadi hak dan kewajibannyaseringkali terlupakan. Dalam kehidupan kenegaraan kadangkala hak warga negara berhadapan dengan kewajibannya.Bahkan tidak jarang kewajiban warga negara lebih banyakdituntut sementara hak-hak warga negara kurang mendapatkanperhatian.Hak dan kewajiban warga negara dalam kehidupankenegaraan maupun hak dan kewajiban seseorang dalamkehidupan pribadinya, secara historis tidak pernah dirumuskansecara sempurna, karena organisasi negara tidak bersifat statis. Artinya organisasi negara itu mengalami perkembangan sejalandengan perkembangan manusia.

Kedua konsep hak dan kewajiban warga negara/manusia berjalan seiring. Hak dankewajiban asasi marupakan konsekwensi logis dari pada hakdan kewajiban kenegaraan juga manusia tidak dapat mengembangkan hak asasinya tanpa hidup dalam organisasi negara.Hak dan kewajiban warga negara dan hak asasi manusiadewasa ini menjadi amat penting untuk dikaji lebih mendalam mengingat 
negara kita sedang menumbuhkan kehidupan demokrasi. Betapa tidak, disatu pihak implementasi hak dankewajiban menjadi salah satu indikator keberhasilan tumbuhnya kehidupan demokrasi. Dilain pihak hanya dalamsuatu negara yang menjalankan sistem pemerintahan demokrasi, hak asasi mnusia maupun hak dan kewajiban warganegara dapat terjamin.Hak asasi manusia marupun hak dan kewajiban warganegara sebagai salah satu elemen penting dari demokrasidisamping supremasi hukum, telah diatur dalam UUD 1945.

Pengaturan hak asasi manusia maupun hak dan kewajibanwarga negara secara lebih operasional ke dalam pelbagaiperaturan perundang-undangan amat bermanfaat. Pengaturandemikian ituakan menjadi acuan bagi penyelenggara Negara agar terhindar dari tindakan sewenang-wenang tatkala mengoptimalisasikan tugas kenegaraan. Sedangkan bagimasyarakat/warga negara hal itu merupakan pegangan/pedoman dalam mengaktualisasikan hak-haknya dengan penuh rasa tanggung jawab. Akan tetapi bagaimana substansi HAM maupun hak dan kewajiban warga negara Indonesia dalam perundang-undangan/ hukum positif menarikuntuk menjadi bahan kajian.

Hak Azasi Manusia (HAM)Istilah HAM pertama kali diperkenalkan oleh Rooseveltketika Universal Declaration of Human Rights dirumuskanpada tahun 1948, sebagai pengganti istilahthe Rights of Man.Dalam konstitusi Indonesia (UUD 1945) digunakan istilah hakwarga negara yang oleh the Founding Father di maksudkansebagai pemenuhan hak asasi manusia. Namun kedua istilahini ( Ham dan hak serta kewajiban warga negara) dipergunakansecara resmi oleh MPR sebagaimana tercantum dalam Amandemen kedua UUD 1945 (Bab X dan Bab X A) maupundalam ketetapan MPR RI Nomor : XVII/1998.HAM merupakan suatu pemikiranyang dituangkan dalambentuk hukum. Pemikiran HAM itu sangat legal formal danbermula di Eropa Barat sebagai tempat munculnya pemikiranliberal. Para pemikir liberal seperti John Locke dan John S. Millyang menekankan pada kebebasan manusia dan Montesquieuserta Rouseau yang menekankan pada equality, menghendakiperlunya pembatasan peran negara/pemerintah.

Menurutpemikiran liberal, negara hanya berperan semata-mata sebagaialat untuk melindungi, menjamin unsur kehidupan,kesejahteraan dan kebebasan. Bahkan lebih ekstrim dapatdikatakan peran negara hanya peronda malam. Pemikiranliberal yang menekankan pada "kebebasan", pada dasarnyamenjunjung tinggi kepentingan individu. Hal mana berbedadengan pemikiran aliran kiri yang menitikberatkan pada“"golongan."Berlainan halnya dengan konsepsi liberal dan aliran kiri,konsepsi HAM menurut versi Indonesia adalah HAM menurutsusunan masyarakat Indonesia. Dapat dikatakan pula konsepsiHAM di Indonesia menitikberatkan pada keseimbangan antarahak Azasi dengan kewajibanasazasi. Perbedaan konsepsi ituterletak pada ide dan aplikasi. HAM meskipun demikian secrasubstansial, HAM merupakan suatu konsep universal yang didalamnya terdapat aspek-aspek 
kemanusiaan sebagai dasaryang tidak boleh dilanggar oleh siapapun dan dalam kondisiapapun.

HAM merupakan hak kodrat, hak dasar manusia, hakmutlak1. Menurut Jan Matenson, HAMadalah hak-hak yangmelekat pada manusia, yang tanpa dengannya manusiamustahil dapat hidup sebagai manusiaz. Menurut Lopa, HAMadalah hak-hak yang diberikan langsung oleh Tuhan Yang1H.A.MansyurEffendi, Hak Azasi Manusia dalam Hukum Nasional dan Internasional, Ghaliah Indonesia Jakarta 1994, hlm .15 Maha Pencipta (hak-hak yang bersifat kodrati). Oleh karenanyatidak ada kekuasaan apapun di dunia yang dapatmencabutnya3.Dalam ketetapan MPR RI Nomor : XVII/1998 disebutkanbahwa HAM merupakan hak dasar yang melekat padadirimanusia yang sifatnya kodrati, universal dan abadi sebagaikarunia Tuhan Yang Maha Esa dan berfungsi untuk menjamin kelangsungan hidup, kemerdekaan, perkembangan manusiadan masyarakat yang tidak boleh diabaikan, dirampas atau diganggu gugat oleh siapapun. Sedangkan dalam Undang-Undang nomor 39 tahun 1999 ditegaskan HAM adalahseperangkat hak yang melekat pada hakekat dan keberadaan manusia sebagai mahluk Tuhan YangMaha Esa dan merupakan anugrahNya yang wajib dihormati, dijunjung tinggidan dilindungi oleh negara, hukum, Pemerintah dan setiaporang demi kehormatan serta perlindungan harkat dan martabat manusia.

Hak azasi individual sebagai hak fundamental yang melekat pada pribadi manusiaindividual ialah hak hidup dan perkembangan hidup.Umpamanya : hak atas kebebasan batin, kebebasan menganutagama, kebebasan dalam hidup pribadi, hak atas nama baik,hak untuk kawin dan hak membentuk keluarga.Sedangkan2Baharudin Lopa,Alqur'an dan HAMPT DanaBakti Prima Yasa Jokyakarta 1996 hlm 13Baharudin Lopa Alqur'an dan HAM PT dana bakti Prima Yasa Jokyakarta 1996, hlm 24Theo Huijbers Filsafat Hukum, Kanisius, Yokykarta 1995 hlm 103.

Hak asazi sosial merupakan hak yang melekat pada pribadi manusia sebagai mahluk sosial yang meliputi hak ekonomis,sosial dan kultural. Umpamanya hak untuk memenuhi kebutuhan hidup (pangan, sandang), kesehatan, kerja,pendidikan. Dalam posisinya sebagai mahluk sosial, individu mempunyai kewajiban untuk membangun hidup bersama agarhak-hak di maksud dapat terwujud.

Oleh sebab itu dapatlah dikatakan budayamerupakan suatu komplex aktivitas dan tindakan manusia yang berpola, salah satu diantaranya hukum positif yang melindungi, danmenjamin perwujudan HAM.(2). Hak dan Kewajiban Warga NegaraHak warga negara adalah suatu kewenangan yang dimiliki olehwarga negara guna melakukan sesuatu sesuai peraturan perundang-undangan. Dengan kata lain hak warga negara merupakan suatukeistimewaan yan menghendaki agar warga negara diperlakukansesuai keistimewaan tersebut. Sedangkan Kewajiban warga negaraadalah suatu keharusan yang tidak boleh ditinggalkan oleh warganegara dalam kehidupan bermasyarkat berbangsa dan bernegara.Kewajiban warga negara 
dapat pula diartikansebagai suatu sikapatau tindakan yang harus diperbuat oleh seseorang warga negarasesuai keistimewaan yang ada pada warga lainnya.Erat kaitannya dengan kedua istilah ini ada beberapa istilahlain yang memerlukan penjelasan yaitu : tanggung jawab dan peranwarga negara.

Tanggunjawab warga negara merupakan suatukondisi yang mewajibkan seorang warga negara untuk melakukantugas tertentu. Tanggung jawab itu timbul akibat telah menerimasuatu wewenang. Sementara yang dimaksud dengan peran warganegara adalahaspek dinamis dari kedudukan warga negara. Apabilaseorang warga negara melaksanakan hak dan kewajiban sesuaikedudukannya maka warga tersebut menjalankan suatu peranan.Istilah peranan itu lebih banyak menunjuk pada fungsi, penyesuaiandiri dan sebagai suatu proses.Istilah peranan mencakup 3 hal yaitu :

a) Peranan meliputi norma yang dihubungkn dengn posisi seseorangdalam masyarakat. Dalam konteks ini peranan merupakan rangkaian peraturan yang membimbing seseorang dalamkehidupan kemasyarakatan.

b) Perananadalah suatu konsep tentang apa yang dapat dilakukanoleh individu dalam masyarakat sebagai organisasi.5Soerjono Soekanto Sosiologi suatu Pengantar, PT Raja Grafindo Persada, Jakarta 1990 HIm 269.8

c) Peranan dapat juga dikatakan sebagai perilaku individu yangp enting bagi struktur sosial masyarakat.Dari pengertian diatas tersirat suatu makna bahwa hak dankewajiban warga negara itu timbul atau bersumber dari negara.Maksudnya negaralah yang memberikan ataupun membebankan hakdan kewajiban itu kepada warganya.

Pemberian/pembebanan dimaksud dituangkan dalam peraturan perundangundangansehingga warga negara maupun penyelenggara negara memilikiperanan yang jelas dalam pengaplikasian dan penegakkan hak sertakewajiban tersebut. Pengaturan HAM, Hak dan Kewajiban Warga Negara dalamHukum PositifHukum positif merupakan aturan hukum yang sedang berlakudisuatu negara. Hukum positif di suatu negara tidaklah sama denganhukum positif yang berlaku di negara lain. Perbedaannya terletakpada konstitutsi yang menjadi dasar dan sumber pembuatan hukum positif di yang maksud.

Hukum positif itu dapat berwujud peraturanperundang-undangan.Di Indonesia konstitusi dimaksud telah mengalami beberapa kalipenggantian, jika selama \pm 4 tahun setelah kemerdekaan (18/8-1945s/d 27/12-1949), diberlakukan UUD 1945 maka selama kurun waktusekitar 8 bulan (27/12-1949 s/d 17/8-1950) berlaku konstitusi RIShampir di seluruh wilayah Indonesia. Akan tetapi konstitusi inidiganti lagi dengan UUDS 1950 yang kemudian dengan dekrit 5 Juli1959 dinyatakan tidak berlaku sekaligus memberlakukan kembaliUUD 1945. Ketiga konstitusi ini berbedasatu sama lain. UUD 1945 yangsangat singkat itu hanya mencantumkan 7 pasal (pasal27,28,29,30,31,33 dan 34) tentang HAM dengan penanaman hakwarga negara. Sedangkan konstitusi RIS 
dan UUDS 1945 merinciHAM secara detail dalam hampir sekitar 30 pasal yang ternyata 9cenderung memiliki kesamaan dengan Universal Declaration ofHuman Rights.

Pengaturan HAM yang sangat terbatas dalam UUD 1945menurut Ahadian disebabkan karena rancangan UUD dibahas dalamsuasana ingin merdeka dari penjajahan Belanda, yang dengansendirinya tidak ingin memuat hal-hal yang berasal dari faham barattermasuk HAM6. Hal ini tercermin dari adanya pro kontra dikalanganpendiri negara tentang urgensi pencantuman HAM dalam UUD.Namun pada akhirnya tercapai konsensus memasukkan HAM kedalam konstitusi dengan pertimbangan untuk membatasi kekuasaanpenguasa.Pembukaan UUD 1945 yang menjiwai pengaturan HAM dalamBatang Tubuh UUD 1945 dan peraturan perundangundangan lainsebagai hukum positif, pada setiap alinea mencerminkan HAM. Jikadalampembukaan UUD alinea pertama dan kedua tercerminpengakuan adanya kebebasan dan keadilan maka alinea ketiga dankeempat mencerminkan adanya persamaan dalam bidang politik,Ekonomi, Hukum, sosial dan budaya. Ini berarti substansi HAMdalam Pembukaan UUD 1945 amat luas tetapi disayangkan kurangmendapatkan penjabaran yang lebih rinci dalam Batang Tubuh UUD1945. Oleh karenanya MPR melalui ketetapan Nomor : XVII/1998maupun perubahan kedua UUD 1945 pasal $28 \mathrm{~s} / \mathrm{d}$ pasal $28 \mathrm{~J}$ lebihmemperjelas dan merinci mana yang merupakan HAM, kewajibanwarga negara.

Pemenuhan Hak dan Kewajiban Warga Negara Indonesia: Telaah Kritis Tentang 'Kegalauan' yang 'Menghantui' Pemerintah Indonesia Setiap pembaca yang cerdas tentunya sebelum mereka membaca atau mempelajari sebuah topik atau mempelajari sebuah permasalahan yang muncul di dalam sebuah literatur, maka pusat perhatian awal mereka akan tertuju kepada sebuah judul yang akan dibahas. Ini artinya dibutuhkan aktiiftas berpikir dalam menjalani kegiatan. Senada dengan apa yang dikemukakan oleh Nadiroh bahwa Berpikir merupakan salah satu kegiatan utama individu dalam menjalani berbagai aktivitas kehidupan (Nadiroh, 2015). Apakah judul itu menarik atau tidak, semua bergantung kepada perspektif orang-orang yang membacanya dan apabila judul itu dianggap menarik, maka orang yang membacanya secara tidak langsung tertarik untuk membaca isi literatur tersebut. Begitupun sebaliknya, apabila judul itu dianggap tidak menarik - bahkan membacanya pun sudah membuat bosan - maka orang yang membacanya tidak akan menaruh perhatian kepada literatur tersebut dikarenakan sedari awal dalam membaca judulnya pun sudah tidak tertarik.

Berangkat dari paradigma di atas, maka dalam uraian ini akan disampaikan alasan mengapa memilih judul "Pemenuhan Hak dan Kewajiban Warga Negara Indonesia: Telaah Kritis Tentang 'Kegalauan' yang ‘Menghantui' Pemerintah Indonesia”. Dalam menentukan judul tersebut, tentunya ada satu pertimbangan yang sudah dipikirkan matang-matang yaitu dalam rangka memilih judul di atas, bukan semata-mata disesuaikan dengan apa yang sedang dipikirkan di kepala, melainkan pemilihan judul 
di atas didasarkan kepada ketertarikan terhadap sesuatu yang membuat seseorang tertarik dengan apa yang ditulis. Ini artinya lebih menitikberatkan kepada sebuah 'daya tarik' teks judul dalam memikat para pembaca.

Sebelum melakukan telaah kritis terhadap 'sajian' judul di atas, ada baiknya kamu mengetahui tentang apa yang akan menjadi output atau manfaat setelah mempelajari dan menelaah dengan kritis topik ini. Sehubungan dengan itu, agar dapat mengetahui apa yang akan menjadi output atau manfaat dalam mempelajari topik ini, maka dari itu akan dijelaskan tujuan dalam memilih judul tersebut, yaitu pertama, dapat membuka pandangan setiap orang tentang 'Kegalauan' yang melanda Pemerintah Indonesia dalam melaksanakan pemenuhan Hak dan Kewajiban Warga Negara Indonesia. Lalu yang Kedua, membangun kesadaran masyarakat Indonesia akan pentingnya melaksanakan Hak dan Kewajibannya sebagai Warga Negara Indonesia.

Kedua tujuan itulah yang akan bersinggungan dengan output atau manfaat yang akan kamu dapatkan nantinya apabila kamu mempelajarinya dengan sungguhsungguh. Substansial Hak dan Kewajiban Warga Negara Indonesi Menurut Notonegoro Hak adalah kuasa untuk menerima atau melakukan suatu yang semestinya diterima atau dilakukan oleh pihak tertentu dan tidak dapat diterima atau dilakukan oleh pihak lain mana pun juga yang pada prinsipnya dapat dituntut secara paksa olehnya. Kewajiban dengan demikian merupakan sesuatu yang harus dilakukan (Paristiyanti Nurwardani, 2016).

Sedangkan menurut Lubis dan Sodeli, Hak Warga Negara merupakan seperangkat hak yang melekat dalam diri manusia dalam kedudukannya sebagai anggota dari sebuah negara (Yusnawan Lubis, 2018). Kemudian ia juga mengatakan bahwa Hak Warga Negara dibatasi oleh status kewarganegaraannya. Kemudian Rusnila menyatakan pendapatnya mengenai Kewajiban Warga Negara dan menurutnya Kewajiban Warga Negara adalah Kewajiban yang melekat bagi tiap-tiap warga negara, seperti halnya membayar pajak, membela tanah air, membela pertahanan dan keamanan negara, dan lain-lain (Rusnila, 2016). Lebih lanjut Lubis dan Sodeli memberikan konsep sederhana mengenai Kewajiban Warga Negara.kewajiban warga negara dibatasi oleh status kewarganegaraan seseorang. Akan tetapi, konsep kewajiban warga negara memiliki cakupan yang lebih luas, karena meliputi pula kewajiban asasi. Misalnya, di Indonesia menghormati hak hidup merupakan kewajiban setiap orang terlepas apakah ia warga negara Indonesia atau bukan. Adapun kewajiban bela negara hanya merupakan kewajiban warga negara Indonesia, sementara warga negara asing tidak dikenakan kewajiban tersebut (Yusnawan Lubis, 2018). Jika berbicara mengenai Hak Warga Negara, secara umum Hak Warga Negara terbagi menjadi dua, yaitu :

1. Hak Sipil dan Politik;

2. Hak Ekonomi, sosial dan budaya; 
Tabel 1. Hak Sipil dan Politik serta Hak Ekonomi, Sosial, dan Budaya

\begin{tabular}{|l|l|}
\hline \multicolumn{1}{|c|}{ Hak Sipil dan Politik } & \multicolumn{1}{|c|}{ Hak Sipil dan Politik } \\
\hline Hak Sipil; & Hak Ekonomi; \\
Hak untuk hidup dan tidak dihukum mati & Hak atas pekerjaan: \\
Hak untuk tidak disiksa & Hak upah yang layak \\
Hak Beragama dan Berkeyakinan & Hak memilih pekerjaan \\
$\begin{array}{l}\text { Hak bagi kaum Minoritas untuk tidak } \\
\text { mendapatkan Diskriminasi dari pihak } \\
\text { manapun }\end{array}$ & Hak-hak Buruh: \\
$\begin{array}{l}\text { Hak mendapatkan tempat tinggal } \\
\text { Hak berkeluarga dan perlindungan anak } \\
\text { Hak untuk tidak diperbudak dalam } \\
\text { bekerja }\end{array}$ & $\begin{array}{l}\text { Hak membentuk dan bergabung dengan } \\
\text { serikat kerja }\end{array}$ \\
\hline $\begin{array}{l}\text { Hak Politik; } \\
\text { Hak Berpendapat, berkumpul, dan adil } \\
\text { berserikat }\end{array}$ & Hak mendapatkan Standard hidup yang \\
$\begin{array}{l}\text { Hak Turut serta dalam pemerintahan, hak } \\
\text { memilih dan dipilih dalam pemilu, dan } \\
\text { akses informasi pemerintahan } \\
\text { persamaan di depan Hukum }\end{array}$ & Hak atas kecukupan Pangan \\
Hak dijadikan Subjek Hukum & Hak terbebas dari Kelaparan \\
\hline
\end{tabular}


Hak Budaya;

Hak atas Pendidikan

Hak atas kehidupan Budaya dan Ilmu Pengetahuan

Dengan demikian dapat ditegaskan kembali bahwa Hak dan Kewajiban merupakan dua hal yang saling berkaitan dalam kehidupan sehari-hari. Apabila seseorang dapat melakukan Kewajibannya, tentu ia akan mendapatkan Hak yang sudah seharusnya ia dapatkan. Hal tersebut seperti banyak kita jumpai dalam kehidupan sehari-hari, misalnya saja ketika seseorang melakukan pekerjaannya sebagai Kewajiban, kemudian di akhir bulan ia mendapatkan Haknya berupa Gaji.

Melihat hubungan Hak dan Kewajiban yang begitu penting namun terkadang hubungan itu dianggap sepele oleh sebagian orang-orang, maka sudah sepantasnya Hak dan Kewajiban itu dimaknai sebagai sesuatu yang penting dalam menjalani kehidupan agar tidak ada orang lain yang merasa dirugikan akibat pengingkaran Hak dan Kewajiban. 'Kegalauan' Pemerintah Indonesia dalam memenuhi Hak dan Kewajiban warga negaranya Setelah mengamati substansi Hak dan Kewajiban Warga Negara Indonesia di atas maka dapat diketahui apa penyebab 'Kegalauan' Pemerintah Indonesia dalam memenuhi kedua komponen tersebut. 'kegalauan yang dimaksud disebabkan oleh ketidakseimbangan antara hak dan kewajiban. Apabila keseimbangan itu tidak ada akan terjadi kesenjangan sosial yang berkepanjangan (Yusnawan Lubis, 2018).

Pendidikan terutama Pendidikan Kewarganegaraan sangat penting diajarkan kepada pelajar maupun Mahasiswa untuk membentuk karakter yang mulia sehingga dapat menjauhkan pengingkaran Hak dan Kewajiban Warga Negara Indonesia untuk kedepannya. Pendidikan kewarganegaraan pada hakikatnya adalah sebuah bentuk pendidikan untuk generasi penerus yang bertujuan agar mereka menjadi warga negara yang berpikir tajam dan sadar mengenai hak dan kewajibannya dalam hidup bermasyarakat dan bernegara, juga bertujuan untuk membangun kesiapan seluruh warga negara agar menjadi warga dunia yang cerdas (Widodo, 2018).

Dengan demikian dapat disimpulkan bahwa Pendidikan Kewarganegaraan harus digalakkan mulai dari tingkatan Sekolah sampai Perguruan Tinggi untuk membentuk generasi bangsa yang dapat melaksanakan Hak dan Kewajibannya sebagai Warga Negara Indonesia secara seimbang dan sebaik-baiknya.

\section{KESIMPULAN}

Kewarganegaraan merupakan keanggotaan seseorang dalam kontrol satuan politik tertentu yang dengannya membawa hak untuk berpartisipasi dalam kegiatan politik. 
Seseorang dengan keanggotaan yang demikian disebut warga negara. Seorang warga negara berhak memiliki paspor dari negara yang dianggotainya.

\section{E. REFERENSI}

Nadiroh. (2015). The Influence of Learning Strategis and Style of Thought on The Ability of Students to Solve Environmental Problems. Jurnal Pendidikan Lingkungan Dan Pembangunan Berkelanjutan, XVI (September 2015), 85-100. https://doi.org/10.21009/PLPB

Paristiyanti Nurwardani, D. (2016). Pendidikan Kewarganegaraan untuk Perguruan Tinggi (Cetakan I). Jakarta: Direktorat Jenderal Pembelajaran dan Kemahasiswaan Kementerian Riset Teknologi dan Pendidikan Tinggi.

Rusnila. (2016). Pendidikan Kewarganegaraan (Civic Education). (Nilwani, Ed.) (Cetakan Pe). Pontianak: IAIN Pontianak Press.

Tryanto. (2013). Regulasi Perlindungan Hak Asasi Manusia Tingkat Internasional. Jurnal PPKn, Vol.1. No.1 Januari 2013, 1(1), 1-8.

Widodo, B. (2018). Membangun Kedewasaan Berpolitik Warga Masyarakat Akademis Melalui Pendidikan Kewarganegaraan. Jurnal Pancasila Dan Kewarganegaraan, 3(1), 70-78. Retrieved from http://journal.umpo.ac.id/index.php/JPK/index\%OAMEMBANGUN

Yusnawan Lubis, M. S. (2018). Pendidikan Pancasila dan Kewarganegaraan KELAS XII SMA/MA/SMK/MAK. (S. P. Muhamad Taupan, Ed.), Kementerian Pendidikan dan Kewarganegaraan (Cetakan ke). Jakarta: Pusat Kurikulum dan Perbukuan, Balitbang, Kemendikbud. 